\title{
Palkokasvit nurmitilan kierrossa
}

Arja Nykänen ${ }^{1)}$, Asko Hannukkala ${ }^{2)}$, Marketta Rinne ${ }^{3)}$ ja Tapio Salo ${ }^{2)}$

1) MTT Kasvintuotannon tutkimus, Lönnrotinkatu 3, 50100 Mikkeli, arja.nykanen@mtt.fi

${ }^{2)}$ MTT Kasvintuotannon tutkimus, 31600 Jokioinen, asko.hannukkala@mtt.fi,tapio.salo@mtt.fi

${ }^{3)}$ MTT Kotieläintuotannon tutkimus, 31600 Jokioinen, marketta.rinne@mtt.fi

\section{Tiivistelmä}

Palkokasvien käyttö on viime aikoina lisääntynyt väkilannoitteiden ja väkirehujen hintojen äkillisten vaihteluiden myötä. Vaikka palkokasvien viljely ei ongelmatonta olekaan, katsotaan riskien kuitenkin monesti olevan pienempiä ja ainakin helpommin hallittavia kuin esimerkiksi maailman markkinahinnat. Nurmitilalla palkokasvien käyttö on helpointa aloittaa apilan lisäämisestä nurmiseoksiin, mutta nurmen välikasvina voidaan viljellä palkoviljoja kuten hernettä, härkäpapua ja jopa lupiinia viljojen kanssa seoksena. Sato voidaan korjata joko puiden tai säilörehuksi. Palkokasvit hyödyntävät karjanlannan ravinteet tehokkaasti ja lisäväkilannoitusta ei välttämättä juurikaan tarvita.

Puna-apila on nurmiemme yleisin palkokasvi, mutta myös alsike- ja valkoapilaa käytetään varsinkin vaihtelevilla lohkoilla. Valkoapila kestää myös laidunnusta ja sinimailasta voi kokeilla hyvärakenteisille vähemmän happamille maille. Palkokasvit tuovat nurmen korjuuaikaan joustoa, koska niiden sulavuus laskee heiniä hitaammin. Palkokasvien biologinen typensidonta toimii tavallaan pellon ja tilan omana typpitehtaana. Tämä tehdas toimii tehokkaimmin, kun palkokasvit viljellään seoksina typpeä sitomattomien kasvien kanssa, typpilannoitus pidetään kohtuullisena ja nurmisato korjataan pois pellolta. Näin palkokasvien viljely ei myöskään lisää typen huuhtoutumista, jota usein pelätään.

Apilan säilyminen nurmissa on koettu jonkin verran ongelmalliseksi. Tähän auttavat nurmen maltillinen lannoitus, uudet satoisat ja hyvin talvehtivat lajikkeet, oikea korjuuajankohta, pellon muotoilut ja toimiva salaojitus, tallausvaurioiden minimoiminen ja apilattomien vuosien pitäminen viljelykierrossa. Nurmea ei pitäisi viljellä ns. nurmesta nurmeen, koska maa "väsyy", kasvitaudit ja monivuotiset rikkakasvit yleistyvät ja sitä kautta satotasot laskevat. Kaura ja rypsi ovat hyviä välikasveja apilanurmen viljelyssä, koska niillä sanotaan olevan puhdistava vaikutus apilan tauteja vastaan. Perinteisen herne-kauran voi viljellä kokoviljasäilörehuksi ja herneeksi kannattaa valita reheväkasvuinen vihantarehuherne, joka tuottaa runsaasti biomassaa ja valkuaista ja on sulavuudeltaan erinomaista. Rypsin viljely nurmen suojakasvina onnistuu hyvin lisäten samalla rapsikuoriaisen luontaisia vihollisia pienentäen näin rypsin viljelyn riskejä.

Rehunurmen apilapitoisuudeksi voidaan suositella 40-50 \% kuiva-aineesta. Tällöin pellon typpitase on tasapainossa, rehun raakavalkuaispitoisuus on noin $14 \%$ ja syönti-indeksikään ei enää nouse tuon osuuden jälkeen. Nämä typpeen liittyvät tulokset on saatu luomunurmista, joita on lannoitettu karjanlannalla pääasiassa nurmen perustamisvaiheessa. Laskelmiin vaikuttavat oleellisesti heinien ja apiloiden typpipitoisuudet, jotka voivat vaihdella suurestikin. Nurmen apilapitoisuutta voi arvioida ottamalla itse näytteitä ja määrittämällä apilapitoisuuden, vertaamalla peltoaan Artturi ${ }^{\circledR}$ verkkopalvelusta löytyviin valokuviin tai sieltä löytyvällä rehun kalsiumpitoisuuslaskurilla.

Asiasanat: alsikeapila, apilapitoisuus, herne, härkäpapu, juurilaho, lupiini, apilamätä, korjuuaika, pahkahome, puna-apila, typpi, valkoapila 


\section{Johdanto}

Kiinnostus palkokasvien viljelyyn on lisääntynyt selkeästi viime vuosina. Syinä tähän ovat pääasiassa väkilannoitteiden, valkuaisrehujen ja viljan suuret hintavaihtelut, mikä luo epävarmuutta ja vaikeuttaa tilan talouden ja toiminnan suunnittelua. Palkokasveihin perustuvan kotovaraisen valkuaisen tuotannon avulla hyödynnetään palkokasvien kyky sitoa typpeä suoraan ilmasta Rhizobium bakteerinsa avulla. näin säästetään myös energiaa, sillä yhden väkilannoitetyppikilon valmistaminen vaatii yhden öljylitran sisältämän energiamäärän (Grönroos ym. 2006). Palkokasvit käyttävät auringon energiaa ja lisäksi lannoitteiden kuljetukseen ja levitykseen tarvittava energia säästetään.

Palkokasvien viljelyyn ja käyttöön rehuna liittyy sekä positiivisia vaikutuksia että ongelmia. Tämän kirjoituksen tarkoituksena onkin valottaa näitä seikkoja kirjallisuuden ja uusimman kotimaisen tutkimuksen tulosten valossa.

\section{Palkokasveissa valinnanvaraa}

Suomessa yleisimmin viljelty palkokasvi monivuotisissa nurmissa on puna-apila, josta on myös saatavilla useita satoisia lajikkeita (Betty, Bjursele, Ilte, SW Torun; Hakala \& Jauhiainen 2009, Niskanen \& Huhta 2008). Nurmiseoksiin voi myös käyttää alsike- ja valkoapilaa antamaan viljelyvarmuutta. Valkoapila sopii laitumiin, koska se kestää tallausta rönsyilevän kasvutapansa vuoksi. Uudemmat lajikkeet, kuten Aber Herald ja Jõgeva, ovat satoisia myös säilörehunurmissa (Nykänen-Kurki 2000, Nykänen ym. 2001). Hyvällä kasvupaikalla sini- ja sirppimailanen tuottavat apiloita korkeampia satoja (Nykänen ym. 2006). Vuohenherne puolestaan sopii pitkäikäisiin nurmiin ja on hyvä kasvi siinäkin mielessä, ettei se puhalluta eikä siinä ole kasviestrogeeneja eikä -tauteja (Valkonen \& von Heiroth 1993, Saloniemi ym. 1993). Palkokasvit kannattaa viljellä seoksina heinien kanssa mm. viljelyvarmuuden lisäämiseksi ja typen huuhtoutumisriskin vähentämiseksi. Palkokasviheinäseokset tuottavat jopa $10000 \mathrm{~kg} \mathrm{ha}^{-1}$ kuiva-ainesatoja kahden niiton systeemissä (Nykänen ym. 2006).

Yksivuotisista palkokasveista meillä sopivat viljelyyn herneet, härkäpapu ja sinilupiini. Yleisimmin näitä viljellään puitavaksi, mutta jos tilalla halutaan tuottaa karkearehua tai kasvit eivät ehdi tuottaa tuleentunutta siementä, voi ne korjata kokokasvustona tuore- tai säilörehuksi. Näissä seoksissa voi käyttää myös rehu- ja ruisvirnaa. Yksivuotisten palkokasvien kanssa kannattaa käyttää viljoja seoksessa (Nykänen ym. 2009a). Härkäpavun viljely onnistuu hyvin puhdaskasvustonakin, mutta herne on rentovartinen kasvi, jolloin vahvakortiset kaura ja vehnä pitävät kasvustot paremmin pystyssä. Lupiinin viljelystä meillä on vielä vähän kokemuksia ja sen viljely todennäköisesti onnistuu myös puhdaskasvustona. Koko kasvuston korjaavissa menetelmissä viljat parantavat seosten viljelyvarmuutta sekä vähentävät esimerkiksi puristenesteen syntymistä.

Yksivuotisia apiloita kuten persianapilaa voi käyttää viljojen aluskasvina. Tätä ei kannata kuitenkaan tehdä, jos nurmissa jo on apilaa, sillä tautipaineen pienentämiseksi on hyvä pitää kierrossa apilattomia vuosia.

\section{Apilan kasvu avainasemassa}

Palkokasvien käytön suurimmat edut ovat niiden typensidonta suoraan ilmasta sekä hyvät ruokinnalliset ominaisuudet. Niinpä niiden kasvu ja pysyminen nurmissa onkin avainasemassa. Sellaiset perusasiat kuin kasvuvyöhykkeelle sopiva lajike, pellon hyvä rakenne, sopiva pH (hiukan alle 6), ravinteet tasapainossa, korjuu pellon ollessa kuiva juuristovaurioiden välttämiseksi, monipuolinen viljelykierto sekä seoskasvustojen viljely täytyy huolehtia ensisijaisesti kuntoon (Nykänen ym. 2007). Tällä hetkellä keskustelua ovat herättäneet nurmen oikea niittoajankohta ennen kasvukauden loppua sekä suorakylvön käyttö apilanurmien viljelyssä. Suositukset nurmen viimeisestä niittoajankohdasta kolme viikkoa ennen kasvukauden loppua ovat 1980-luvun alkupuolelta (Huokuna 1979), mutta kasvihuoneilmiön edettyä ja edetessä tätä tulisi tutkia ja tarkastella uudelleen. Monivuotisten palkokasvien talvehtimisen kannalta on juuristoon talven ajaksi kerätyn vararavinnon määrällä suuri merkitys. Suorakylvö on erinomainen tapa täydentää apilaa nurmiin, koska tällöin siemen pääsee hyvin maakosketukseen (Nykänen ym. 2004). Mutta rikkooko kone apiloiden juuristoa liikaa ja mikä on sopivin ajankohta kylvölle: keväällä, ensimmäisen vai toisen sadonkorjuun jälkeen?

Typensidonnan tehokkuuden kannalta tärkeitä tekijöitä ovat tehokkaan typpibakteeriympin käyttö, palkokasvien viljely typpeä sitomattomien kasvien kanssa ja itse palkokasvin hyvä kasvu. Maassa luontaisesti elävät typpibakteerit eivät ole niin tehokkaita sitomaan typpeä kuin kaupallisten 
ymppivalmisteiden kannat. Ne eivät myöskään nystyröi kaikkien palkokasvien kanssa eli ovat isäntäspesifisiä. On myös havaittu, että typensidonnan teho on korkea, kun itse isäntäkasvi kasvaa hyvin (Lindström 1984). Teho on myös suurimmillaan silloin, kun kasvi on juuri tulossa kukkaan (Lindström 1984). Tämä on myös useimpien palkokasvien sulavuuden kehityksessä vaihe, jolloin se kannattaa korjata rehuksi (Rinne \& Nykänen 2000). Koska typensidonta vaatii kasvilta enemmän energiaa kuin typen ottaminen maasta, ottaa palkokasvi typpeä mieluummin maasta, jos sitä vain on siellä tarjolla (Høgh-Jensen \& Schørring 1994). Tästä syystä viljely seoskasvustoina typpeä sitomattomien kasvien kanssa tehostaa typensidontaa, sillä yksisirkkaiset kasvit ottavat tehokkaasti maassa olevan liukoisen typen (Ledgard 2001).

\section{Huomio myös typpitalouteen}

Tavanomaisessa nurmiviljelyssä palkokasvien lisääminen nurmeen ei vaikuta viljelytoimenpiteisiin juuri muutoin kuin että nurmen typpilannoitus täytyy mukauttaa nurmen apilapitoisuuden mukaan ja sadonkorjuuajankohdan valinnassa täytyy palkokasvien osuus kasvustossa ottaa huomioon ja viivyttää korjuuta tarpeellisessa määrin..

Nurmen palkokasvipitoisuuden määrittäminen ei ole ongelmatonta, sillä esimerkiksi apilapitoisuus vaihtelee runsaasti eri vuosina, jokaisessa niitossa ja myös pellon sisällä (Nykänen ym. 2008a). Pellon apilapitoisuutta voi verrata $\operatorname{Artturi}^{\circledR}$-palvelussa näkyviin valokuviin, sen voi määrittää itse erottelemalla kasvustonäytteistä eri kasvilajit, tai siitä voi saada arvion säilörehunäytteen kalsiumpitoisuuden perusteella (Rinne ym. 2008a).

Nurmen perustamisvaiheessa karjatilalla käytetään karjanlantaa, mikä onkin hyvä lannoite palkokasveille, koska ravinteet vapautuvat siitä kasvien käyttöön hitaammin kuin väkilannoitteista. Kasvuvuosien täydennyslannoitus on syytä pitää kohtuullisena, sillä liian suuret typpimäärät ja erityisesti väkilannoitteiden liukoisen typen määrät hävittävät palkokasvit kasvustoista heinien saadessa liian suuren kilpailuedun. Lisäksi apilan elinvoima heikkenee, kun se ottaa typen maasta eikä sido ilmasta. Vanha suositus typpimääristä pitänee edelleen paikkansa. Jos apilapitoisuus on yli $50 \%$ kuiva-aineesta, lisätyppeä voi antaa nurmelle $0-30 \mathrm{~kg} \mathrm{ha}^{-1} \mathrm{v}^{-1}$ ja jos apilapitoisuus on alle $20 \%$, typpeä voi antaa $80 \mathrm{~kg} \mathrm{ha}^{-1} \mathrm{v}^{-1}$ (Saarela 1986). Sopivan apilapitoisuuden eli noin 40-50\% kuiva-aineesta omaavalle nurmelle typpeä voisi antaa $50 \mathrm{~kg} \mathrm{ha}^{-1} \mathrm{v}^{-1}$.

Tietoa nurmen apilapitoisuudesta voidaan hyödyntää myös ruokinnan suunnittelussa sekä typensidonnan määrän arviointiin typpitaseiden laskennassa. Kun tiedetään nurmen apilapitoisuus ja kokonaissadon määrä, saadaan typensidonnan määrä laskettua laskukaavan avulla (Nykänen ym. 2008a). Typpitaseiden laskennassa tulee ottaa huomioon, että nurmikasvuston juuristoon, sänkeen ja maahan sadonkorjuun yhteydessä pudonneisiin kasvin osiin on sitoutunut $40 \%$ nurmipalkokasvien koko biomassan ilmasta sitomasta typestä (Høgh-Jensen ym. 2004)

Jos palkokasvien viljelyllä halutaan olevan lannoitusvaikutusta myös niiden jälkeen viljeltäville kasveille, täytyy typen peltotaseen olla positiivinen palkokasvien viljelyn osalta. Tämä saavutetaan esimerkiksi apilapitoisten nurmien viljelyssä, kun nurmen apilapitoisuus on keskimäärin yli $50 \%$ (Nykänen 2008). Palkokasvien jälkeisen typpilannoitusvaikutuksen tutkimuksia on tehty jonkin verran Nykänen ym. 2008b), mutta vielä ei ole pystytty kehittämään mallia tai laskukaavaa, jolla voitaisiin luotettavasti ennustaa apilapitoisen nurmen lannoitusvaikutus esimerkiksi seuraavalle viljakasville, vaikka kiinnostus sellaisen kaavan kehittämiselle olisi suuri, jotta voitaisiin arvioida lisälannoitustarpeen suuruutta.

Apilan satotasojen perusteella voidaan myös mallintaa seuraaville viljelykasveille välittyvää typpilannoitusta. Ruotsalaisen COUP -mallin testaus osoittautui lupaavaksi (Nykänen ym. 2009b), mutta simulointimallit tarvitsevat runsaasti lähtötietoja. Keskeiset tiedot typen mineralisaation mallintamiseen ovat apilakasvustosta maahan jäävän kasvimateriaalin sekä maan muun eloperäisen aineksen määrien ja koostumusten arviointi.

\section{Kasvitaudit hallintaan välikasveilla ja viljelytekniikalla}

Apilamätä (Sclerotinia trifoliorum) ja tavallinen pahkahome (S. sclerotiorum) ovat pahimmat apilaa ja muita nurmipakokasveja uhkaavat hyvin lähisukuiset taudinaiheuttajat (Willetts \& Wong 1980). Pahkahome vioittaa myös hernettä ja härkäpapua (Bolton ym. 2006). Pahkahomeen on todettu vahingoittavan yli 400 eri kasvilajia, joten taudin hallinta viljelykierron avulla on haasteellista (Boland \& Hall 1994). Apilamätä oli Suomessa 1950 - 1960 luvuilla erittäin vakava talvituhojen aiheuttaja 
puna-apilalla (Ylimäki 1969). Viime vuosina apilamätä ei ole aiheuttanut isoja ongelmia, mutta nurmipalkokasvien viljelyn lisääntyessä taudin merkitys todennäköisesti jälleen kasvaa (Yli-Mattila ym. 2009). Tavallisen pahkahomeen merkitystä ei Suomessa ole kartoitettu, mutta tautia kyllä löytyy kaikista meillä viljellyistä palkokasveista (Hannukkala, julkaisematon tieto).

Apilamätä voi vaurioittaa erityisen pahasti nuoria, reheviä apilakasvustoja. Tauti iskeytyy herkästi apilaan kylvövuoden syksyllä ja tuhoaa pahimmillaan koko kasvuston ensimmäisen talven aikana ennen kuin yhtään satoa on korjattu (Ylimäki 1969, Willetts \& Wong 1980). Tavallinen pahkahome puolestaan vaurioittaa reheviä kasvustoja loppukesällä ja on potentiaalinen uhka yksivuotisille palkokasveille (Bolton ym. 2006). Pahkahomeen takia yksivuotiset palkokasvit eivät ole paras valinta ainakaan viljelykiertoihin, joissa apilan osuus on suuri (Hannukkala 2005).

Apilamätä ja pahkahome säilyvät maassa sklerootioina (rihmastopahkoina). Apilamädän sklerootioiden elinikä on 5-7 vuotta ja pahkahomeen $3-5$ vuotta. Rihmastopahkoista kehittyy sopivan kosteissa ja ilmavissa oloissa pieniä lakkisieniä muistuttavia itiöemiä, kotelomaljoja. Itiöemien yläpinnalla muodostuu suunnattomia määriä koteloitiöitä, jotka voivat levitä tuulten mukana kymmenien kilometrien päḧhän syntypaikastaan. Hyvä viljelykierto vähentää lohkokohtaista tartuntariskiä, muttei estä tautien leviämistä edellisvuosien palkokasvilohkoilta (Willetts \& Wong 1980).

Pohjakallion (1963) mukaan apilamätä nousi 1900-luvun alkupuoliskolla nopeasti vakavaksi puna-apilan viljelyn esteeksi, kun apilanviljely yleistyi. Jo 1940-luvulla apilamädän tuhovoima alkoi laantua, koska erilaiset apilamädän rihmastopahkoissa loisivat sienet (esim. Coniothyrium minitans ja Episclerotium sclerotiorum) alkoivat luontaisesti yleistyä apilapelloilla (Erviö 1965). Myös viimeaikaiset selvitykset (Yli-Mattila ym. 2009) antavat viitteitä, että luonnonmukaisesti viljellyillä pelloilla, joilla apilaa on viljelty toistuvasti, apilamädän luontaisia vihollisia on enemmän kuin tavanomaisesti viljellyillä pelloilla.

Vaikka hyvä kasvinvuorotus on välttämätöntä palkokasvien viljelyssä, apilamädän ja pahkahomeen hallintaan on muitakin keinoja. Nurmipalkokasvien seosviljely heinäkasvien kanssa on tuottavuuden kannalta edullista (Nykänen ym. 2006) ja vähentää tautiriskejä puhdaskasvustoihin verrattuna (Ylimäki 1969). Sclerotinia-lajien rihmastopahkojen tuhoamiseen on biologisia torjuntakeinoja, joista pahkoissa loisivasta Conithyrium minitans sienestä (Whipps \& Gerlagh 1992). on kehitetty tehokas kaupallinen torjuntavalmiste, Contans WG joka on rekisteröity pahkahomeen ja apilamädän torjuntaan useissa EU-maissa (Whipps ym. 2007), mutta ei Suomessa.

Nykyviljelyssä eniten sadonalennuksia ja apilan häviämistä pelloista aiheuttaa juurilaho, joka puolestaan vaivaa vanhempia kasvustoja. Fusarium-sienet tunkeutuvat kasvin juureen ja lahottavat sitä sisältä. Raskaat koneet, laiduntaminen sekä liian lyhyt niittokorkeus altistavat kasveja patogeenin siirtymiselle kasviin juuristovaurioiden myötä (Ylimäki 1967, Hannukkala 2005).

\section{Palkokasvit sopivat hyvin nautojen ruokintaan}

Rehuntuotannon ja viljelyn kannalta nurmipalkokasvien parhaimpia puolia on, että ne antavat joustoa rehujen korjuuaikatauluun. Tämä johtuu siitä, että niiden sulavuus eli D-arvo kehittyy nurmissa hitaammin kuin heinien erityisesti alkukesällä. Keskimäärin puna-apilan sulavuuden lasku alkukesällä on noin puolet hitaampaa kuin nurmiheinien (Rinne \& Nykänen 2000, Rinne ym. 2007, Kuoppala ym. 2010). Myös kokoviljasäilörehua tehtäessä herneiden ja virnojen sulavuus ei muutu niin nopeasti kuin viljoilla (Nykänen ym. 2009a, 2010). Ennuste oikean korjuuajan valitsemiseksi puna-apilapitoisille

nurmille löytyy Artturi ${ }^{\circledR}$-verkkopalvelun Korjuuaikatiedotuksesta (www.mtt.fi/artturi). Korjuuaikapäätöstä tehtäessä on muistettava, että apila ei paranna seoksessa mukana kasvavien nurmiheinien sulavuutta ja apilan osuus tulee usein arvioitua todellista suuremmaksi.

Apilapitoiset nurmet voi siis korjata puhtaita heinänurmia myöhemmin, jolloin niiden sulavuus on samaa luokkaa. Käytännössä niiden sulavuus on usein jonkin verran matalampi kuin puhtaissa heinänurmissa. Tämä ei sinänsä haittaa mitään, sillä apilapitoisten nurmirehujen merkittävä ominaisuus on se, että lehmät syövät niitä enemmän kuin puhtaista heinänurmista tehtyjä säilörehuja. Tämä on otettu huomioon myös säilörehun syönti-indeksin laskukaavassa, jossa apilapitoisuus vaikuttaa positiivisesti $50 \%$ apilapitoisuuteen saakka. (Huhtanen ym. 2007, Rinne ym. 2008b). Parempi syönti näkyy myös korkeampina maitotuotoksina, jos verrataan rehuja, joiden D-arvo on sama. 
Apilapitoisia rehuja pidetään usein haastavampina säilöttävinä, koska ne ovat tyypillisesti kosteampia kuin heinäkasvisäilörehut ja niiden puskurikapasiteetti on korkeampi. Käytännössä apilapitoisten rehujen säilyminen onnistuu kuitenkin yleensä yhtä hyvin kuin puhtaiden nurmiheinäkasvustojen. Säilöntäaineen käyttö varmentaa säilöntätulosta (Saarisalo \& Rinne 2005).

Eri kasvilajien oikeudenmukainen vertailu on vaikeaa, mutta voidaan sanoa, että apiloissa on pääsääntöisesti enemmän raakavalkuaista ja vähemmän kuitua kuin nurmiheinissä (Huhtanen ym. 2006, MTT 2006). Juvalla kerättiin 10 luomukarjatilalta säilörehunäytteitä kolmen vuoden ajalta ja verrattiin niiden kalsiumpitoisuuden perusteella laskettua apilapitoisuutta ja raakavalkuaispitoisuutta. Tuloksena havaittiin, että säilörehun raakavalkuaispitoisuus $14 \%$ saavutettiin keskimäärin $40 \%$ apilapitoisuudella ( $\mathrm{R}^{2}=0,45$, Nykänen 2009 , julkaisematon tulos).

Väkirehutäydennyksen määrä ja laatu kivennäisruokintaa lukuun ottamatta (Tuori 2007) voidaan apilapitoisille rehuille suunnitella samojen periaatteiden mukaisesti kuin nurmiheiniä perusrehuina käytettäessä. Maidontuotanto lisääntyi Rinteen ym. (2006) kokeessa rypsi- ja soijapuristeita annettaessa yhtä paljon kuin tyypillisesti nurmiheinäpohjaisilla ruokinnoilla vaikka säilörehusta puolet oli apilaa. Vanhatalo ym. (2009) totesivat että erityisesti välttämättömän aminohapon metioniinin pitoisuus oli varsin pieni apilasäilörehua saaneiden lehmien verenkierrossa heinäsäilörehua saaneisiin lehmiin verrattuna, mikä voi osaltaan selittää apilapitoisten säilörehujen valkuaisen huonohkoa hyväksikäyttöä.

Puna-apilapitoisen säilörehun käytön voi odottaa pienentävän maidon rasva- ja valkuaispitoisuuksia jonkun verran. Puna-apila kuitenkin muutti heinäkasveihin verrattuna maidon rasvakoostumusta siten, että kerta- ja monityydyttymättömien rasvahappojen osuus lisääntyi tyydyttyneiden rasvahappojen kustannuksella (Vanhatalo ym. 2007), millä voidaan katsoa olevan positiivisia vaikutuksia maitotuotteita käyttävien ihmisten terveydelle.

Merkittävänä ongelmana palkokasvien käytössä nautojen ruokinnassa pidetään niiden sisältämiä kasviestrogeeneja sekä puhalluttamisominaisuuksia. Lypsykarjan hedelmällisyysongelmat ovat erittäin yleisiä vaikka apilaa ei ruokinnassa käytettäisi ja lukuisat syyt voivat aiheuttaa niitä. Vaikka apiloissa voi olla merkittäviä määriä kasviestrogeenejä, ei ole todennäköistä, että ne vaikuttaisivat merkittävästi nautojen hedelmällisyyteen (Mustonen 2007). Puhaltuminen on laiduntamiseen ja niittorehun syöttöön liittyvä ongelma, johon auttaa $\mathrm{mm}$. se että ei laske lehmiä yhtäkkiä rehevään ja/tai kylmään kasvustoon. Palkokasveissa on myös runsaasti kalsiumia ja magnesiumia, mikä on otettava huomioon kivennäisruokinnassa (Tuori 2007). Ummessa olevien lehmien ruokintaan apilapitoinen säilörehu on huono vaihtoehto, koska sen korkea kalsiumpitoisuus lisää merkittävästi poikimahalvausriskiä.

Nautojen ruokinnassa voidaan käyttää myös palkoviljoja eli hernettä, härkäpapua tai uusimpana tulokkaana lupiinia. Härkäpavun ja lupiinin siementen käytöstä nautojen ruokinnassa ei ole kotimaisia tutkimustuloksia, mutta niiden voi olettaa soveltuvan käytettäväksi ainakin osana valkuaistäydennystä. Herne ei ole osoittautunut aivan rypsirouheen veroiseksi valkuaistäydennykseksi lypsylehmien ruokinnassa (Khalili ym. 1999, Ahvenjärvi ym. 2005). Palkoviljoja käytettäessä on muistettava huomioida niiden alhaisempi raakavalkuaispitoisuus (230-340 $\mathrm{g} \mathrm{kg}^{-1}$ kuiva-ainetta) verrattuna rypsija soijapohjaisiin (310-400 $\mathrm{g} \mathrm{kg}^{-1}$ kuiva-ainetta) valkuaisrehuihin (MTT 2006). Palkoviljat sopivat hyvin myös yksimahaisten ruokintaan osittaiseksi soijan korvaajaksi (Partanen ym. 2003, 2006).

\section{Johtopäätökset}

Monivuotiset palkokasvit sopivat erinomaisesti nautakarjatilan nurmiin ja niiden viljely ja käyttö ei tuota suuria ongelmia varsinkaan säästettyihin lannoitekustannuksiin verrattuna. Yksivuotisia palkokasveja voi käyttää myös kierrossa joko puitavaksi tai säilörehuksi. Palkokasvit kannattaa kuitenkin viljellä seoksina heinien tai viljojen kanssa viljelyvarmuuden lisäämiseksi sekä' kasvitautipaineen ja typen huuhtoutumisriskin vähentämiseksi.

\section{Kirjallisuus}

Ahvenjärvi, S., Vanhatalo, A. \& Jaakkola, S. 2005. Herne lisää lehmien maitotuotosta. Koetoiminta ja käytäntö 62, 2(13.6.2005): s. 6.

Boland, G.J., \& Hall, R. 1994. Index of plant hosts of Sclerotionia sclerotiorum. Canadian Journal of Plant Pathology 16: 93-108.

Bolton, M.D., Thomma, B.P.H.J. \& Nelson, B.D. 2006. Sclerotinia sclerotiorum (Lib.) de Bary: biology and molecular traits of a cosmopolitan pathogen. Molecular Plant Pathology 7: 1-16. 
Erviö, L-R. 1965. Certain parasites of fungal sclerotia. Journal of the Scientific Society of Finland 37: 1-6. Grönroos, J., Seppälä, J., Voutilainen, P., Seuri, P. \& Koikkalainen, K. 2006. Energy use in conventional and organic milk and rye bread production in Finland. Agriculture, Ecosystems and Environment 2-3: 109-118.

Hakala, K. \& Jauhiainen, L. 2007. Yield and nitrogen concentration of above- and below-ground biomasses of red clover cultivars in pure stands and in mixtures with three grass species in northern Europe. Grass and Forage Science 62, 3: 312-321.

Hannukkala, A. 2005. Nurmi- ja nurmikkokasvit.Apila.Kasvitaudit. In: Ajankohtaisia kasvinsuojeluohjeita. Kasvinsuojeluseuran julkaisuja 100: 57-59.

Huhtanen, P., Nousiainen, J. \& Rinne, M. 2006. Recent developments in forage evaluation with special reference to practical applications. Agricultural and Food Science 15: 293-323.

Huhtanen, P., Rinne, M. \& Nousiainen, J. 2007. Evaluation of the factors affecting silage intake of dairy cows: a revision of the relative silage dry-matter intake index. Animal. 1: 758-770.

Huokuna, E 1979. K- ja E- Suomessa korjuu heti syyskuun alkupäivinä. Koetoiminta ja käytäntö 36 (28.8.1979): 30 .

Høgh-Jensen, H., Loges, R., Jørgensen, F.V., Vinther, F.P. \& Jensen, E.S. 2004. An empirical model for quantification of symbiotic nitrogen fixation in grass-clover mixtures. Agricultural Systems 82: 181-194.

Høgh-Jensen, H. \& Schørring, J.K. 1994. Measurement of biological dinitro-gen fixation in grassland: comparison of the enriched $15 \mathrm{~N}$ dilution and the natural $15 \mathrm{~N}$ abundance methods at different nitrogen application rates and defoliation techniques. Plant and Soil 166: 153-163.

Khalili, H., Saarisalo, E., Suvitie, M. \& Kuusela, E. 1999. Herne ja rypsi valkuaisrehuina luonnonmukaisessa maidontuotannossa. Koetoiminta ja käytäntö 56, 1(23.2.1999): 2.

Kuoppala, K., Rinne, M., Tuori, M. Pursiainen, P. \& Vanhatalo, A. 2010. Puna-apilakasvuston kehitysrytmi alku- ja loppukesällä. Maataloustieteen Päivät 2010. Saatavilla Internetissä: www.smts.fi.

Ledgard, S.F. 2001. Nitrogen cycling in low-input legume-based agriculture, with emphasis on legume/grass pasture. Plant and Soil 228: 43-59.

Lindström, K. 1984. Analysis of factors affecting in situ nitrogenase (C2H2) activity of Galega orientalis, Trifolium pratense and Medicago sativa in temperate conditions. Plant and Soil 79: 329-341.

MTT 2006. Rehutaulukot ja ruokintasuositukset 2006. MTT:n selvityksiä 106. 86 s. Saatavilla Internetissä: http://www.mtt.fi/mtts/pdf/mtts106.pdf

Mustonen, E. 2007. Puna-apilan kasviestrogeenivaikutukset. Puna-apilaa nurmiin ja ruokintapöydälle. Punaapila tehokkaasti luomumaidoksi -tutkimushankkeen päätösseminaari 17.4.2007. Suomen Nurmiyhdistyksen julkaisuja 25: 23-33. https://portal.mtt.fi/portal/page/portal/nurmiyhdistys/Julkaisut/punaapila/mustonen.pdf

Niskanen, M. \& Huhta, H. 2008. Puna-apila. In: Arjo Kangas, Taina Harmoinen (toim.). Peltokasvilajikkeet 2008. Maaseutukeskusten Liiton julkaisuja 1050: Tieto tuottamaan 122: 79-80.

Nykänen, A. 2008. Nitrogen dynamics of organic farming in a crop rotation based on red clover (Trifolium pratense) leys. Agrifood Research Reports. 121. 60p. (Diss.). http://www.mtt.fi/met/pdf/met121.pdf

Nykänen, A., Avikainen, H., Jauhiainen, L., Leinonen, P. \& Nykänen-Kurki, P. 2004. Apilanurmen apilapitoisuuden säätely kylvöä jaksottamalla. In: Maataloustieteen Päivät 2004, Suomen Maataloustieteellisen Seuran tiedote 19: 4 s. www.smts.fi/MTP\%20julkaisu\%202004/posterit04/kr25.pdf

Nykänen, A., Granstedt, A., Jauhiainen, L. \& Laine, A. 2008b. Residual effect of clover-rich leys on soil nitrogen and successive grain crops. Agricultural and Food Science. 17, 1: 73-87.

Nykänen, A., Granstedt, A., Laine, A. \& Kunttu, S. 2000. Yields and clover contents of leys of different ages in organic farming in Finland. Biological Agriculture \& Horticulture. 18, 1: 55-66.

Nykänen, A., Jauhiainen, L., Kemppainen, J. \& Lindström, K. 2008a. Field-scale spatial variation in soil nutrients and in yields and nitrogen fixation of clover-grass leys. Agricultural and Food Science. 17, 4: 376-393.

Nykänen, A., Jauhiainen, L., Nissinen, O. \& Tuori, M. 2006. Nurmipalkokasvien optimaalinen korjuuaika. In: Anna-Maija Heikkilä (toim.). Laatulihaa tehokkaalla emolehmätuotannolla . MTT:n selvityksiä 113: 27-35.

Nykänen, A., Jauhiainen, L. \& Palojärvi, A. 2007. Kuinka maaperä vaikuttaa puna-apilanurmen kasvuun? Puna-apila tehokkaasti luomumaidoksi -tutkimushankkeen päätösseminaari 17.4.2007. Suomen $\begin{array}{lllll}\text { Nurmiyhdistyksen } & \text { julkaisuja } & \text { 25: } & \text { S-10. } & \text { Satavilla }\end{array}$ https://portal.mtt.fi/portal/page/portal/nurmiyhdistys/Julkaisut/punaapila/nykanen1.pdf

Nykänen, A., Jauhiainen, L. \& Rinne, M. 2009a. Biomass production and feeding value of whole-crop cereallegume silages. Agronomy Research. 7, 2: 684-690.

Nykänen, A., Leinonen, P. \& Nykänen-Kurki, P. 2001. Havaintoja yksi- ja monivuotisista nurmipalkokasveista luomuviljelyssä. In: Nurmitutkimuksen satoa - tuloksia lannoituksesta, palkokasveista, luomunurmista, laitumista, ruokonadasta. Suomen Nurmiyhdistyksen julkaisu 14: 41-48.

Nykänen, A., Salo, T. \& Granstedt, A. 2009b. Simulated cereal nitrogen uptake and soil mineral nitrogen after clover-grass leys. Nutrient Cycling in Agroecosystems. 85, 1: 1-15.

Nykänen, A., Rinne, M. \& Jauhiainen, L. 2010. Palkokasveista valkuaista ja sulavuutta kokoviljaseoksiin. Maataloustieteen Päivät 2010. Saatavilla Internetissä: www.smts.fi. 
Nykänen-Kurki, P. 2000. Valkoapila. In: toim. Aulis Järvi ja Hanne Teräväinen. Peltokasvilajikkeet 2000. Maaseutukeskusten Liiton julkaisuja 951: Tieto tuottamaan 87: 69-70.

Partanen, K., Siljander-Rasi, H. \& Alaviuhkola, T. 2006. Feeding weaned piglets and growing-finishing pigs with diets based on mainly home-grown organic feedstuffs. Agricultural and Food Science 15, 2: 89-105.

Partanen, K., Alaviuhkola, T., Siljander-Rasi, H. \& Suomi, K. 2003. Faba beans in diets for growingfinishing pigs. Agricultural and Food Science in Finland 12, 1: 35-47.

Pohjakallio, O. 1963. Kasvipatologia II. Tarttuvat kasvitaudit. Werner Södeström Osakeyhtiö, Porvoo, Helsinki.375 s.

Rinne, M. \& Nykänen, A. 2000. Timing of primary growth harvest affects the yield and nutritive value of timothy-red clover mixtures. Agricultural and Food Science in Finland. 9, 2: 121-134.

Rinne, M., Kuoppala, K., Ahvenjärvi, S. \& Vanhatalo, A. 2006. Rypsi soijaa parempi lypsylehmien valkuaistäydennys myös apilapitoista säilörehua syötettäessä. Julkaisussa: Maataloustieteen Päivät 2006 Suomen Maataloustieteellisen Seuran julkaisuja no 21. /www.smts.fi/esit06/1002.pdf.

Rinne, M., Nykänen, A., Nyholm, L., Nousiainen, J. \& Vanhatalo, A. 2007. Kehitysrytmi huomioitava apilanurmen korjuussa. Puna-apila tehokkaasti luomumaidoksi -tutkimushankkeen päätösseminaari 17.4.2007. Toim. A. Vanhatalo \& M. Topi-Hulmi Suomen Nurmiyhdistyksen julkaisuja 25: 23-33. Saatavilla Internetissä: https://portal.mtt.fi/portal/page/portal/nurmiyhdistys/Julkaisut/punaapila/rinne.pdf

Rinne, M., Huhtanen, P. \& Nousiainen, J. 2008b. Säilörehun ja koko rehuannoksen syönti-indeksit auttavat lypsylehmien ruokinnan suunnittelussa. Julkaisussa: Maataloustieteen Päivät 2008. Suomen Maataloustieteellisen Seuran tiedotteita no 23. www.smts.fi/mpol2008/index_tiedostot/Esitelmat/es086.pdf

Rinne, M., Nykänen, A., Kemppainen, J., Nyholm, L. \& Nousiainen, J. 2008a. Nurmikasvuston punaapilapitoisuuden voi ennustaa kalsiumpitoisuudesta. Julkaisussa: Maataloustieteen Päivät 2008. Suomen Maataloustieteellisen Seuran tiedotteita no 23. www.smts.fi/mpol2008/index_tiedostot/Posterit/ps078.pdf

Saarela, I. 1986. Ravinnetarve. Julkaisussa Apilan viljely. Maatalouskeskusten Liiton julkaisuja N:o 730: 22-26. Saarisalo, E. \& Rinne, M. 2005. Biologiset säilöntävalmisteet luomusäilörehujen laadun tukena. Luomulehti 1/2005, pp. 12-14.

Saloniemi, H., Kallela, K. \& Saastamoinen, I. 1993. Study of the phytoestrogen content of goat's rue (Galega orientalis), alfalfa (Medigaco sativa) and white clover (Trifolium repens). Agricultural Science in Finland. 2,6: 517-524.

Tuori, M. 2007. Puna-apilarehu vaatii erilaisen kivennäislisän. Puna-apila tehokkaasti luomumaidoksi tutkimushankkeen päätösseminaari 17.4.2007. Suomen Nurmiyhdistyksen julkaisuja 25: 42-47. https://portal.mtt.fi/portal/page/portal/nurmiyhdistys/Julkaisut/punaapila/tuori.pdf

Valkonen, J. \& von Heiroth, W. 1993. Taudit eivät vaivaa rehuvuohenhernettä. Koetoiminta ja käytäntö vol. 50. 2.3.1993.

Vanhatalo, A., Kuoppala, K., Rinne, M., Pursiainen, P. \& Tuori, M. 2007. Puna-apilasäilörehu lypsylehmien ruokinnassa. Puna-apila tehokkaasti luomumaidoksi -tutkimushankkeen päätösseminaari 17.4.2007. Suomen Nurmiyhdistyksen julkaisuja 25:

34-41. https://portal.mtt.fi/portal/page/portal/nurmiyhdistys/Julkaisut/punaapila/vanhatalo.pdf

Vanhatalo, A., Kuoppala, K., Ahvenjärvi, S. \& Rinne, M. 2009. Effects of feeding grass or red clover silage cut at two maturity stages in dairy cows. 1. Nitrogen metabolism and supply of amino acids. J. Dairy Sci. 92: 5620-5633.

Whipps, J.M \& Gerlagh, M. 1992. Biology of Coniothyrium minitans and its potential for use in disease biocontrol. Mycological Research 96:897-907

Whipps, J,M, Sreenivasaprasad, S., Muthumeenakshi,S., Rogers, C.W. \& Challen, M.P. 2007. Use of Coniothyrium minitans as a biocontrol agent and some molecular aspects of sclerotial mycoparasitism. European Journal of Plant Pathology 121:323-330.

Willetts, H.J. \& Wong, J.A-L. 1980. The biology of Sclerotinia aclerotiorum, S. trifoliorum and S. minor with emphasis on specific nomenclature. The Botanical Review 46: 101-165.

Yli-Mattila, T., Kalko, G., Hannukkala, A., Paavanen-Huhtala, S. \& Hakala, K. 2009. Prevalence, species composition, genetic variation and pathogenicity of clover rot (Sclerotinia trifoliorum) and Fusarium spp. in red clover in Finland. European Journal of Plant Pathology 15 p. (In press). doi:10.1007/s10658-009-9516-1

Ylimäki, A. 1967. Root rot as a cause of red clover decline in leys in Finland. Annals of Agricultrae Fenniae 6, Supplement 1:1-56.

Ylimäki, A. 1969. Apilamätä apilan talvehtimisen heikentäjänä Suomessa. Journal of Scientific Agricultural Society in Finland 41:222-242. 